\title{
Back school and postural habits of women from the Tabajara indigenous community: a quali-quantitative, participatory, and ethnographic approach
}

\author{
Escola de postura e hábitos posturais de mulheres da comunidade indígena Tabajara: uma \\ abordagem quali-quantitativa, participativa e etnográfica
}

Escuela de espalda y hábitos posturales de mujeres de la comunidad indígena Tabajara: un enfoque cual-cuantitativo, participativo y etnográfico

Received: 01/12/2022 | Reviewed: 01/18/2022 | Accept: 01/22/2022 | Published: 01/24/2022

\author{
Gilza de Holanda da Silva \\ ORCID: https://orcid.org/0000-0003-2082-5635 \\ Federal University of Paraiba, Brazil \\ E-mail: gilzahsp@ gmail.com \\ Nivaldo Antonio Parizotto \\ ORCID: https://orcid.org/0000-0003-1774-9053 \\ Federal University of Paraiba, Brazil \\ University Brasil, São Paulo, Brazil \\ E-mail: nivaldoaparizotto@hotmail.com \\ Maria Cláudia Gatto Cardia \\ ORCID: https://orcid.org/0000-0001-5866-860X \\ Federal University of Paraiba, Brazil \\ E-mail: gattocardia@gmail.com \\ Juerila Moreira Barreto \\ ORCID: https://orcid.org/0000-0001-7502-7097 \\ Federal University of Paraiba, Brazil \\ E-mail: juerila@gamil.com
}

\begin{abstract}
Objectives: The Back School is a therapeutic-pedagogical method for the preservation of good postural habits, reeducation of posture and prevention of pain in the spine. To know the postural habits of the Tabajara indigenous community through the realization of a sensitization workshop on care of the spine. Methods: This is an action, participatory and ethnographic research with a qualitative/quantitative approach. Fourteen women aged between 18 and 70 years participated. The instruments were inventory of correct and incorrect postural images and postural assessment form. Conclusion: The sum of the posture frequency was 165 to inadequate postures and 92 for appropriate postures. Qualitative analysis highlights that in the CIs of the questions: What are your expectations regarding this work? $78.6 \%=$ Learning the new; Have your expectations been met? $92.8 \%=$ Learning; Did the spine theme addressed contribute to improve your self-knowledge? $85.7 \%=$ Correct use of the spine; How do you feel at the end of the event? $85.7 \%=$ Emotional satisfaction; Pain in your spine? $85.7 \%=$ feel pain. Practice implications: The study showed that there is involvement in the spine with pain, which may be related to inadequate postures, and it can change using education for health approach.
\end{abstract}

Keywords: Indigenous people; Ethnography; Back school; Health education.

\section{Resumo}

Objetivos: A Escola de Coluna é um método terapêutico-pedagógico para a preservação de bons hábitos posturais, reeducação da postura e prevenção de dores nas costas. Conhecer os hábitos posturais da comunidade indígena Tabajara através da realização de uma oficina de sensibilização sobre cuidados com a coluna. Métodos: Trata-se de uma pesquisa-ação, participativa e etnográfica com abordagem qualitativa/quantitativa. Participaram 14 mulheres com idade entre 18 e 70 anos. Os instrumentos foram inventário de imagens posturais corretas e incorretas e ficha de avaliação postural. Conclusão: A soma das frequências posturais foi de 165 para posturas inadequadas e 92 para posturas adequadas. A análise qualitativa destaca que nos ICs das questões: Quais são suas expectativas em relação a este trabalho? 78,6\%= Aprendendo o novo; Suas expectativas foram atendidas? 92,8\%= Aprendizagem; O tema coluna abordado contribuiu para melhorar seu autoconhecimento? $85,7 \%=$ Uso correto da coluna; Como você se sente ao final do evento? $85,7 \%=$ Satisfação emocional; Dor na coluna? $85,7 \%=$ sente dor. Implicações para a prática: $\mathrm{O}$ estudo mostrou que há acometimento da coluna vertebral com dor, que pode estar relacionada a posturas inadequadas e pode mudar tal situação com a abordagem da educação para a saúde.

Palavras-chave: População indígena; Etnografia; Escola de postura; Educação em saúde. 


\begin{abstract}
Resumen
Objetivos: La Escuela de Espalda es un método terapéutico-pedagógico para la conservación de buenos hábitos posturales, reeducación de la postura y prevención del dolor en la columna vertebral. Conocer los hábitos posturales de la comunidad indígena Tabajara a través de la realización de un taller de sensibilización sobre el cuidado de la columna vertebral. Métodos: Se trata de una investigación acción, participativa y etnográfica con enfoque cualitativo/cuantitativo. Participaron 14 mujeres con edades entre 18 y 70 años. Los instrumentos fueron inventario de imágenes posturales correctas e incorrectas y formulario de evaluación postural. Conclusión: La suma de la frecuencia de posturas fue de 165 para posturas inadecuadas y 92 para posturas adecuadas. El análisis cualitativo destaca que en los IC de las preguntas: ¿Cuáles son sus expectativas con respecto a este trabajo? 78,6\%= Aprendiendo lo nuevo; ¿Se han cumplido sus expectativas? 92,8\%= Aprendizaje; ¿El tema de la columna abordado contribuyó a mejorar su autoconocimiento? 85,7\%= Uso correcto de la columna; ¿Cómo te sientes al final del evento? 85,7\%= Satisfacción emocional; ¿Dolor en la columna? $85.7 \%=$ siente dolor. Implicaciones para la práctica: El estudio mostró que hay compromiso de la columna vertebral con el dolor, que puede estar relacionado con posturas inadecuadas y puede cambiar utilizando el enfoque de educación para la salud.
\end{abstract}

Palabras clave: Población indígena; Etnografía; Escuela de postura; Educación para la salud.

\title{
1. Introduction
}

Back School (School of Postures) was developed in Sweden in 1969, at the Hospital Danderyd under the direction of Zachrisson-Forssel (1981) with the objective of workers helping themselves, taking care of their backs (back care) based on ergonomic counseling. The Swedish precursor model reinforces the importance of educational classes using didactic material and demands results in changing postural habits. These are characteristics that favor health promotion (Meng et al., 2017).

A systematic review from the Cochrane library carried out by Heymans et al. (2004) analyzed a total of 19 Back School programs (3584 patients) and concluded that only 6 trials were of high methodological quality. The results showed moderate evidence that schools of postures provide better effects on recurrent pain and chronic functional status. They also found moderate evidence for the control of chronic low back pain in occupational settings.

Despite the low or very low quality of the evidence, the results for all treatment comparisons, outcomes, and followup periods investigated in this updated systematic review that showed no difference or a trivial effect auspicious of Back School for chronic low back pain. There are a lot of variants on the Back School approach regarding the employment of different exercises and educational methods (Parreira et al., 2017).

The "National Policy for the Attention to Health of Indigenous Peoples" from Brazil Government aims to ensure indigenous people access to comprehensive health care, in accordance with the principles and guidelines of the Unified Health System (SUS). Such principles were ensured in Ordinance No. 254 (Gabinete do Ministro, 2002), by contemplating social, cultural, geographical, historical and political diversity, in order to benefit the overcoming of the factors that make this population more vulnerable to health problems of greater relevance and quality among Brazilians, certifying the efficacy of their medicine and the right of these people to their culture (Gabinete do Ministro, 2002).

According to Oliveira (2012), the organization of health care services for indigenous peoples is provided through the Special Indigenous Sanitary Districts (SISD) and Base Poles, at the local level, bringing together indigenous lands and municipalities. Since the National Health Foundation (Fundação Nacional de Saúde - FUNASA) is responsible for providing primary care through the work of Multiprofessional Indigenous Health Teams (MIHT), composed of medical doctors, nurses, dentists, nursing assistants, indigenous health agents (IHA) and indigenous health agent's sanitation (IHAS). Several health professionals are tempted to address indigenous people's health, among whom we find nurses, who show that special care must be taken with this population (Santos et al., 2021). For care about posture and prevention of inappropriate postural habits, a physiotherapist seems to be the indicated professional. There are still many challenges to be faced related to meeting the health needs of the population, as well as the need to train two professionals to act appropriately to the needs of indigenous people (Oliveira et al. 2021). 
The MIHT, especially by nursing team, promoted the integration between the local health system and indigenous wisdom, so that, through cultural approaches, it makes possible to understand the cultural universe of Potiguaras, their practices related to health and diseases, thus making control interventions more effective, especially in relation to infectious and parasitic diseases (Oliveira, 2012), and postural attitudes involving deformities and pain in the spine (Parizotto, 2007).

However, nobody tried to investigate the postural habits in an indigenous community. For this reason, we choose the Tabajara indigenous community (Paraíba state, Brazil) using a workshop to raise awareness about spinal care.

We identified, through the collective subject discourse (CSD), the expectations of the community in relation to the care of the spine. After detected the presence of low back pain among the members of the Tabajara indigenous community, we guide care actions for the spine through the Back School method for posture adjustment.

\section{Methodology}

Ethnographic research was carried out (Lima, 2010) with a qualitative and quantitative approach using an interpretivist understanding of the problem. The research presents a holistic view with to obtaining the broadest possible description of postural habits in the domestic and/or professional activities of the members of the Tabajara indigenous community, allowing a descriptive record of the material and behavioral culture of that group. (Neves, 2006)

Many of the individuals of the Indian tribe complain about back pain and by one of the authors to be part of the community, we arise the possibility of collaborating with the group through health education. However, a general diagnosis of health conditions, especially in relation to body posture was performed by broader and general mechanism for the community.

\section{Scenario, participants, and sampling strategy}

The research was carried out in the village of Vitória, Mata da Chica, Municipality of Conde, State of Paraíba, Brazil. Adults and elderly who were willing to participate in the project, women between 18 and 70 years old, able to inform about their postural habits in everyday life, and who are open to receive information about body posture and who can improve their posture according to the activities they develop in the daily life of the local reality.

\section{Ethical issues pertaining to human subjects}

All participants agreed to participate, they signed a FICF, as established by Resolution 466/2012 of the National Health Council. This project was sent to Chief of Village for science and acquiescence and later to FUNAI that they signed agreeing. Then it was referred to the Research Ethics Committee of the Health Sciences Center of the Federal University of Paraíba and the project was approved under CAAE No.: 18020819.10000.5188.

\section{Data collection methods}

The community members participated in a single workshop in which they reported their activities of daily living, using the following instruments:

1) Public images of the Brazilian Spine Rehabilitation Association regarding inadequate and adequate postural positions (Associação Brasileira de Reabilitação da Coluna, 2019).

2) Photographic records and videos were made about the statements regarding the participants' postural habits.

3) Verbal recording from a conversation round table to detect low back pain and possible spinal care strategies and postural education.

A poster for the dissemination of the workshop was made and it started at 9:00 am with the chief of tribe performing a ritual Tore dance, after which the participants were invited to go to a room at the chief's residence, and a group dynamics 
technique was used (in which they made a badge and presented themselves from everyday objects of the group such as maraca, cassava and others and put their names. They were asked to report what they expected from the job, the project's objectives were explained. Then a conversation round table was opened for them to talk about their spine and how they felt about it. Then, an instrument with several right and wrong images was presented so that she could identify the postures they performed most in their day-to-day activities, after answering, a moment was opened for them. Explanations about the functioning of the neck (cervical); back (dorsal) and waist and hip (lumbar and sacral) in sequence and a postural orientation moment was performed.

\section{Data processing}

All material recorded during the Round Table has been identified and transcribed to select the data that would be used as quantitative strategy and some of them to enable qualitative strategies.

The wrong postures, the description of pain report from indigenous woman in different conditions of life activities were tabulated and counted to make a quantitative approach.

The words expressed by these women during the meeting have been transcribed and are subject to a qualitative approach, which in the results are placed to define some of their expectations about the health education process for that population and individuals.

All phrases and expressions reported at the meeting were not identified, preserving the safety of data collected in the survey.

\section{Procedures}

A conversation round table was developed based on "words" that generated and guided themes such as: care for the spine. In the construction of collective knowledge and the recording of the speeches were in recorded media or filmed with the group's previous permission. To this goal, a meeting was held based on popular health education. The theme of the meeting consists of welcoming, raising expectations, general information about the project, collecting information from the spine and postural habits in everyday life from the people included.

The data was double checked by two researchers and if they have dubious interpretations, a third member was called to emit opinion about the correct interpretation of the subject.

The meeting started at 9:00 am with the Cacique of Tribe performing a ritual Toré dance. After which the participants were invited to go to a room at the Cacique's residence, after accommodation of all participants, a group dynamics technique was used (in which they made a badge and presented themselves from everyday objects of the group such as maraca, cassava and others.

They were asked to report what they expected from the work, the project's objectives were explained and asked to sign the free informed consent form (FICF). Afterwards, a conversation meeting was opened so that they could talk about their spine and how they felt about it. Then, an instrument with several right and wrong images was presented so that she could identify the postures they performed most in their day-to-day activities. After answering, a moment was opened for them to give explanations about the functioning of the neck (cervical); back (dorsal) and waist and hip (lumbar and sacral). Figure 1 shows the frequency of the positions identified among the participants. We can observe that there is a higher absolute numerical value of inadequate postures (165) in relation to the adequate ones (92) performed by the participants in their daily lives.

In sequence, a postural orientation moment was performed. The results corroborate the incidence of people in the indigenous community with pain and spinal problems. 


\section{Results}

You can see that the blue color bars provide a visual highlight of the high incidence of inappropriate postures in relation to those suitable for carrying out domestic or professional activities, adopted by the participants (Figure 1). After surveying the most frequent postures in daily life, guidelines were carried out based on the recommendations of the Brazilian Spine Rehabilitation Association. (Associação Brasileira de Reabilitação da Coluna, 2019).

An analysis of the testimonies collected from the participants was carried out on some questions raised during the workshop. At first, the expectation of the participants was raised regarding the work that would be carried out. The most significant excerpt of the text was selected, based on the question asked and organized in the methodological figures called Key Expressions (KE), Central Idea (CI) and Collective Subject Discourse (CSD) (Lefèvre, 2017).

The KE are pieces, excerpts from the discourse, which must be highlighted by the researcher that reveals the essence of the content of the discourse or the underlying theory. The central idea (CI) is a name or linguistic expression that reveals, describes and names, in the most synthetic and precise way possible, the meaning present in each analyzed response and in each homogeneous set of KE.

The set of KE later give rise to the CSD. Anchoring (AC) is the expression of a given theory or ideology that the author of the speech professes and that is embedded in his speech as if it were any statement.

Figure 1: Frequency distribution of variety (correct and incorrect) body postures of the women from Tabajara people collected during the meeting related to figures showed to them.

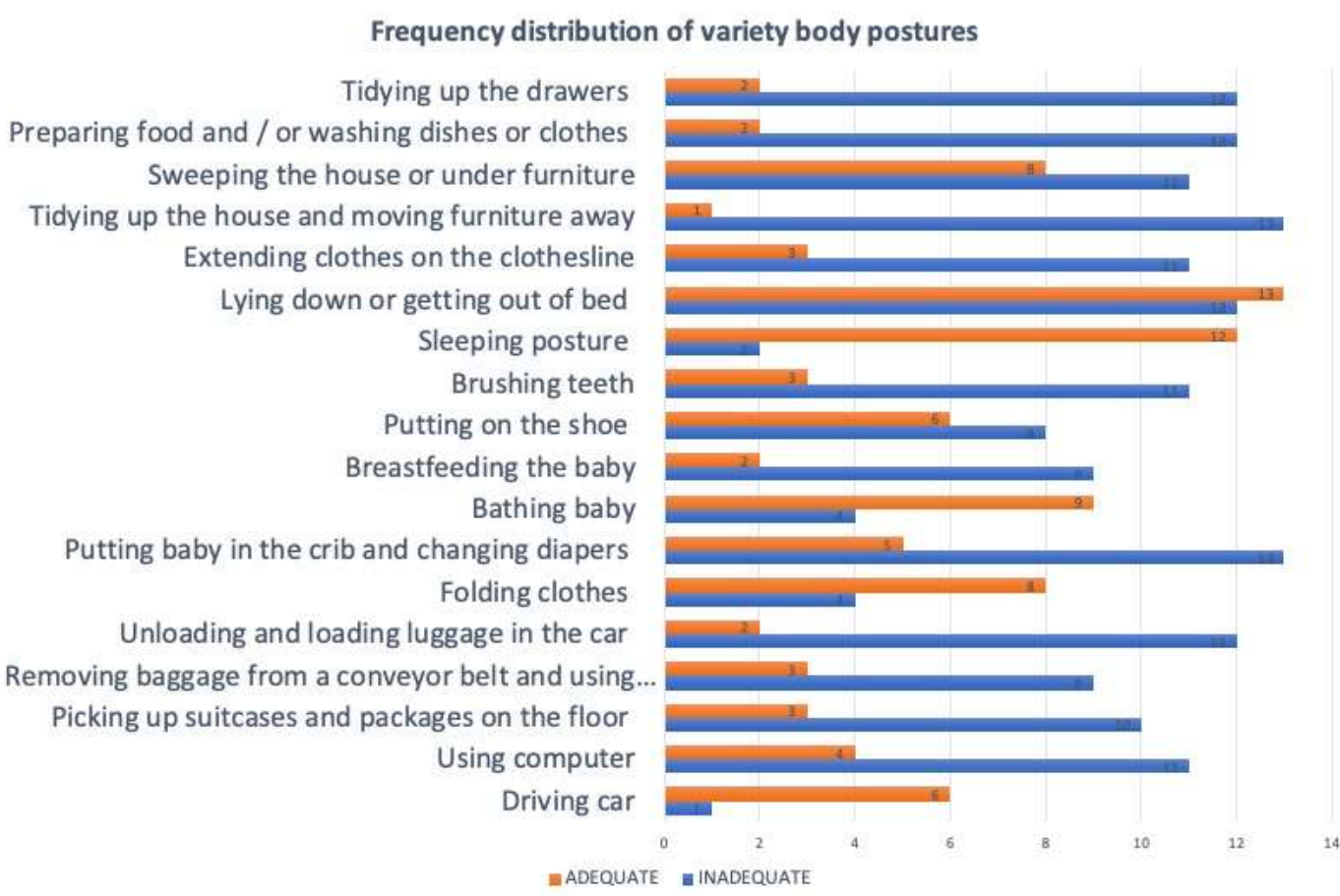

Source: Silva et al. (2022).

The testimonies followed the stages of analysis of the discourse, each testimony was analyzed individually, and its essential content was captured.

The collective subject discourse (CSD) is achieving in a single synthesis discourse written in the first person singular of the KE that have similar or complementary CI or AC. (Lefèvre, 2017). In addition, the percentage calculation was carried out to verify the frequency, in percentage, of the quantity of expressions presented by the participants (Table 1). 


\section{Evidence of the empirical data}

CSD: "May I learn and understand everything about the spine that is part of our body and pass on something new to improve the posture and health of each woman. I hope the day will be rich in knowledge, and that our conversation will be productive and that the work will be of quality and that it will strengthen our people".

We can see in the text that understanding and learning about the spine is important because it is part of the body and that they would like to know more about how to improve posture and health, and that such an undertaking is important. We can also perceive an expectation directed at the wealth of knowledge, productivity and quality work in order to strengthen not only one person but a group.

After the workshop, a final evaluation was carried out with the purpose of verifying the impressions of the participants about the activity developed as follows. Have your expectations been met? When answering this question, $92.8 \%$ reported that their expectations were met and justified in the CSD.

Table 1 - Topics covered at the meeting with their key expressions (KE) (about the questions) that resulted in central ideas (CI) commented upon after the event. The numbers (n) and percentages (\%) of respondents for these central ideas are reported in the speeches of the participating women.

\begin{tabular}{l|clc}
$\begin{array}{l}\text { Key Expressions } \\
\text { (KE) }\end{array}$ & $\begin{array}{r}\text { TOTAL } \\
(n=14)\end{array}$ & \multicolumn{1}{c}{$\begin{array}{c}\text { Central idea } \\
(C I)\end{array}$} & $\begin{array}{c}\text { Percent of response } \\
(\%)\end{array}$ \\
\hline $\begin{array}{l}\text { Expectation about work } \\
\text { Fulfillment of expectation }\end{array}$ & 11 & Learning new concepts & 78.6 \\
$\begin{array}{l}\text { The spine theme contributed to improve } \\
\text { knowledge? }\end{array}$ & 11 & Apprenticeship & 78.6 \\
$\begin{array}{l}\text { How do you feel at the end of the event? } \\
\text { Do you feel pain in your spine? }\end{array}$ & 12 & Correct use of the spine & 85.7 \\
& 12 & Emotional satisfaction & 85.7 \\
\end{tabular}

Source: Silva (2022).

CSD: "I learned the functions of the spine the impacts of bad habits and how to reduce these impacts using the spine correctly. I learned what I didn't know; tips that will help me on a day-to-day basis. The explanation and clarifications were very good. It was great. I cleared a lot of doubts."

When reflecting on the extent to which expectations were met, we observed that $92.8 \%$ reported that they learned about the functions and impacts of bad habits on the spine, and that explanation, clarifications, as a way of helping in the morning.

Another important point was to check with the participants how much this information could contribute to their daily lives, presented in the obtained CSD.

CSD: "I learned many things to improve the spine. I learned how to use the spine and the correct positions to get up on a daily basis. It was important for me to know and learn how to use the column. Taking good manners for the quality of my health. I already knew many positions, but it was good to learn and have more knowledge."

When examining the speech above, we observed that "learning" was very important for self-care. Learning how to use the spine correctly in daily life, in health care, it is worth mentioning that it was informed that many positions were already known, but which was good to learn more about.

When conducting this workshop, it was important to check how the participants felt at the end of the event, we highlight these findings in the DSC. 
DSC: "I am happy to have known the work on the spine. I am very satisfied and very gratified to learn, it was cool. More knowledge has contributed to our daily use of postures. I learned a lot of new things."

When considering the statement above, we observed that there was a feeling of gratification, of being happy to have known the work on the spine, to learn and that it will serve to contribute to the daily life when carrying out their day-to-day activities.

This event had as its main objective to verify if the participants felt some kind of pain in the spine, presented in the DSC.

DSC: "I feel a lot of pain in my spine, when I do housework; I get a lot of pain here in this lower back bone and this part here hurts so much that I can't even raise my arms and this part back here also in this curve hurts a lot; there are days that I don't I can't even move and it's been a long time; I don't even know how long I feel pain in my spine; I try to settle down and support my spine in the best way; I feel some pain, here in the lower part and a little above, in the cervical; I am a person who does not have much posture, I get more stooped. After I went up and down a ladder six times, it caused me some pain here in the back, a deep pain, and it multiplied, the medicine didn't work, it eased a little, I couldn't sleep. I spent about 20 days, when the radiography hit of the cervical spine, the doctor said that my spine was completely destroyed, I took medicine, injections, anti-inflammatory, I have already done several physical therapies, but with the spine it is chronic, the pain doesn't go away, I have two neck injuries, it seems that there is a needle stuck in and the legs also hurt a lot, there are days that it is even difficult to get up, I was hit in the lumbar I spent a long time with the spine hurting a lot, I feel that it didn't feel good, sometimes that little pain comes back that I stay still for a long time without the spine responding, when I work, and I attend many clients (Manicure) then the cervical begins to burn a lot because of the position, I am bent over so much that this here is already high, when I am doing something heavy, tidying up the house my neck is really swollen and I spend a few days. I have a back problem, she has an S, I feel a lot of back pain, it is unbearable pain, it hurts a lot, and when it is raining it really hurts, it hurts a lot, I also feel a lot of pain here in the bones because I have osteoarthritis."

We can see the statement that many women few pains during their daily activities in the spine or with origin from. For this reason, we propose a health education approach to improve the selfcare to all these women and maybe they can teach their descendants to take such care regarding bodily health.

\section{Discussion}

This study aimed to learn about the postural habits of the Tabajara indigenous community through the realization of a workshop to raise awareness about spinal care. The group was totally female (100\%) because the sample was intentional for this type of population. Women are very active in their roles as caregivers of the family, the home, and also in the exercise of professional activities, in addition to experiencing changes in the biomechanics of the spine during pregnancy (CARVALHO et al., 2017), hormonal changes during menopause (Antunes et al., 2003), thus being exposed to a variety of impacts on the spine that may favor the appearance of low back pain.

Studies carried out by Neto et al. (2016) with 200 academics of which $81 \%$ were female, and $66 \%$ had a higher prevalence of lower back pain. The quantitative analysis makes evident the absolute numerical value of 165 inadequate postures, which were higher in relation to the 92 appropriate postures reported by the members of the workshop. We can infer that such incidence can corroborate the reports of pain and spinal problems reported by this population.

Research carried out by Parizotto (2007) on postural attitudes of the indigenous population of Reserva Francisco Hosta Barbosa in the city of Dourados, State of Mato Grosso do Sul, Brazil, due to the high incidence of postural problems existing in the population in general, in which 246 young people from a population of 583 adolescents of both sexes, aged 
between 11 and 22 years were evaluated, it was found that $84.2 \%$ had hyperkyphosis, $77.7 \%$ hyperlordosis, $83.7 \%$ scoliosis. These data provide information for subsequent interventions to the population related to future low back pain (Parizotto, 2007).

When considering the qualitative analysis carried out based on the Collective Subject Discourse, we can reflect on the Central Idea "Learn the new" that emerged from the question: What are your expectations regarding this work? According to Bessa (2008), learning is the act or effect of learning; take note of; retain in memory through study, observation or experience; he becomes able or capable of something as a result of the study. Learning is a continuous process that occurs throughout the individual's life, from birth, through childhood, adulthood and old age. In children, basic learning, such as walking, speaking, reading, writing, are important for citizenship and active participation in society. For adults, activities related to work are more relevant as a way of meeting basic needs that guarantee their livelihood for them. older people can continue to learn complex things, such as a language, or review destructive health habits.

According to Santos et al. (2017), the progress of knowledge in this millennium will only be possible from a transdisciplinary perspective. Where the different areas of knowledge will make use of their assumptions to advance towards new knowledge. In the same perspective, Zaro et al. (2010) point out that "the next generation of educators, will need to take into account the knowledge generated by neuroscience research, when planning and developing their teaching and learning projects".

When considering the Central Idea "Learning", which is linked to the previous paragraph, arising from the question: Where your expectations met? According to Pohlenz (2011), learning is a process of adapting to changing circumstances and the fixation of the mechanisms of success and failure involved in the process is an adaptation acquired as a result of the transactions between the organism and the environment. Our life experiences form the basis of information for neural knowledge networks; the information of what we see, hear and feel produces information and learning that has been stored in the brain and retrieved by the mind (Pohlenz, 2011).

Taking the considerations of Pohlenz (2011), that the brain has infinite capacity for storing information, but storing does not mean the complex relationship of functioning and creation of thinking. Add to all this the processing of information externalized after understanding in a language, developed throughout its history in the capacity of communication. Thus, our life experiences form the basis for the formation of neural networks of knowledge; the information of what we see, hear and feel produces information and learning that are stored in the brain and retrieved by the mind. In this context, we highlight learning with spine care proposed by the educational-therapeutic method of the Back School (Cardia, 2006). A work trying to prevent back pain problems has been implemented with very interesting results in nurses, as it draws attention to interventions that aim to prevent and reduce the occurrences and lower intensities of back pain. In addition, it presented elements of improper movements that increase the loads in the lower part of the spine, in addition to describing the inadequate techniques of handling the patients. Therefore, the program was efficient in the performance of this professional group, with possibilities of similarity of possible results in other people (Járomi et al., 2018).

The problem of inequity among indigenous populations is great and is even more acute when it is addressed to women. For the day-to-day activities of the community and for the care of children and husbands, in addition to their own care, women have an overload of work in the community. For this reason, the population of indigenous women was chosen to participate in this study. This type of situation has already been discussed among indigenous people in Mexico, where the focus has been on health education, care for their own health and the establishment of referral mechanisms for the regular health care system in the municipality or state for women. under different conditions (Pelcastre-Villafuerte, 2014). In our case, women understood that care is paramount for maintaining health and allowing for an improved life. 


\section{Conclusion}

It was possible to observe that the majority of indigenous women descended from Tabajara people, living today in the village of Vitória, adopt inadequate postures when carrying out activities of daily living, which can cause pain in their spine, and the most reported pains were low back pain.

The study revealed that the inadequate postural habits as an expression of the participants' relationship with their daily chores is very present in the life of each of the members of community participating in the workshop. However, it is evident that they are open to learning to new possibilities to implement new customs to reduce aggression to the spine.

The Back School method as an educational program can be a pleasant alternative and with great prospects of implementing positive results with the original indigenous peoples who, like all of us, suffer the aggravations of the inappropriate use of the spine when carrying out their activities of daily living. It would be important to implement postural education sessions, to reinforce appropriate postural habits, with practical educational classes, physical exercises and relaxation.

We conclude that in order to minimize the problems on the spine, it is possible to carry out an educational-therapeutic activity based on the Back School method directed at the Tabajaras indigenous people, as well as physical activities aimed to reducing spinal pain and deformities, which improves their performance in the their daily life, in domestic services and as a final recommendation, refers to Physiotherapy treatment for the inhabitants of the village who already report feeling pain in the spine. It is very important to keep in mind that the indigenous people have their own characteristics, and they must be considered to carry out any health intervention. It is suggested that there be people from within the community to have greater realism and identification with the rituals of the village to collect data and make interventions.

\section{Limitations of findings}

The data collected in this work refer to an indigenous community integrated in the routine life of a city in the northeastern region of Brazil, and therefore, adapted to the civilizing habits of the Brazilian people. For this reason, it is not possible to apply these conclusions obtained through this qualitative and quantitative study for isolated indigenous pollutions, without contacts with the civilized world. Therefore, the generalization of the concepts raised by this study should be avoided.

\section{Conflicts of interest}

The authors declare no conflicts of interest and we conduct the study analysis and conclusions without external interferences or influences.

\section{Acknowledgments}

We thank the Cacique of the Tribo Tabajara and all the other people who participated in this study.

\section{References}

Antunes, S., Marcelino, O. \& Aguiar, T. (2003) Fisiopatologia da menopausa. [Physiopathology of menopause.] Revista Portuguesa de Clínica Geral. 19: 353-7,

ABRC. (2019). Guia de Postura Dr. Coluna. Associação Brasileira De Reabilitação De Coluna - ABRC. https://www.portaldaenfe rmagem.com.br/downloads/guia-de-postura-dr-coluna.pdf.

Bessa V.H. (2008). Teorias da Aprendizagem. IESDE, Brasil.

Cardia M. C. G. (2006) Manual da escola de postura. João Pessoa: Editora Universitária/UFPB (3a ed.). 
Carvalho, M. E. C. C., Lima, L. C., Terceiro, C. A. L., Pinto, D. R. L., Silva, M. N., Cozera, G. A. \& Couceiro, T. C. M. (2017) Lombalgia na gestação. [Back pain in the pregnancy.] Revista Brasileira de Anestesiologia. 67(3): 266-70,

Gabinete do Ministro. (2002). Portaria de no 254, de 31 de janeiro de 2002, a "Política Nacional de Atenção à Saúde dos Povos Indígenas. [Ordinance No. 254, of January 31, 2002, the "National Policy for the Health Care of Indigenous Peoples.] http://www.funasa.gov.br/site/wpcontent/files_mf/Pm_254_2002.pdf.

Heymans, M. W., Van Tulder, M. W., Esmail, R., Bombardier, C. \& Koes, B. W. Cochrane Database of Systematic Reviews, Issue 1. Chichester: John Wiley \& Sons Ltd, 2008. Back schools for non-specific low-back pain.

Járomi, M., Kukla, A., Szilágyi, B., Simon-Ugron, A., Bobaly, V. K., Makai, A., Linek, P., Ács, P. \& Leidecker, E. (2018) Back School programme for nurses has reduced low back pain levels: A randomized controlled trial. J. Clin. Nurs. 27(5-6): e895-e902,

Lefèvre, F. Discurso do sujeito coletivo. Nosso modo de pensar, nosso eu coletivo. [Discourse of the collective subject. Our way of thinking, our collective self.] São Paulo, Andreoli, 2017, 80p.

Lima, C. L. S. Etnicidade indígena no contexto urbano. Uma etnografia sobre os Kalabaça, Kariri, Potiguara, Tabajara e Tupinambás de Crateús. [Indigenous ethnicity in the urban context. An ethnography about the Kalabaça, Kariri, Potiguara, Tabajara e Tupinambás de Crateús.] 2010. Thesis (Doctorate in Anthropology) Program of Post-Graduation in Anthropology, Federal University of Pernambuco, PE, Brazil.

Meng, K., Peters, S. \& Faller, H. (2017) Effectiveness of a standardized back school program for patients with chronic low back pain after implementation in routine rehabilitation care. Patient Education and Counseling 100: 1161-8.

Neto, M. G., Sampaio, G. S. \& Santos, P. S. (2016) Frequência e fatores associados a dores musculoesqueléticas em estudantes universitários. Revista Pesquisa em Fisioterapia. 6 (1), 26-34,

Neves, V. F. A. (2006) Action research and ethnography: crossed paths. [Pesquisa-ação e etnografia: caminhos cruzados.] Pesquisa e Práticas psicossociais. 1(1): $1-16$.

Oliveira, R. C. C., Silva, A. O., Maciel, S. C. \& Melo, J. R. F. (2012) Situação de vida, saúde e doença da população indígena potiguara, aldeia São Francisco, em Baía da Traição-PB. [Life situation, health and illness of the indigenous population from Potiguara, São Francisco village, in Baía da Traição-PB.] REME Revista Mineira de Enfermagem. 16(1): 81-90.

Oliveira, F. G. de, Oliveira, P. C. P. de, Oliveira Filho, R. N. B. de, Moura, H. S. D., Silva, D. G. da, Lima, R. C. C., \& Santos, M. L. F. dos (2021) Challenges of the indigenous population to access to health in Brazil: integrative literature review. Research, Society and Development. 10(3), e47710313203. 10.33448/rsd-v10i3.13203. https://rsdjournal.org/index.php/rsd/article/view/13203.

Parizotto Z. A. M. Estudos das atitudes posturais em escolares indígenas da reserva de Dourados/MS. [Studies of posture attitudes in indigenous schoolchildren from the Dourados/MS reserve.] Brasília. University of Brasília and University Center of Grande Dourados. 2007 - 146p. Master Dissertation in Health Sciences. Program Minter Multidisciplinary, Brazil.

Parreira, P., Heymans, M.W., Van Tulder, M.W., Esmail, R., Koes, B. W., Poquet, N., Lin, C. W. C. \& Maher, C. G. (2017) Back Schools for chronic nonspecific low back pain. Cochrane Database of Systematic Reviews Issue 8. Art. No.: CD011674. 10.1002/14651858.CD011674.pub2.

Pelcastre-Villafuerte, B., Ruiz, M., Meneses, S., Amaya, C., Márquez, M., Taboada, A. \& Careaga, K. (2014) Community-based health care for indigenous women in Mexico: a qualitative evaluation. International Journal for Equity in Health 13:(2): 1-9.

Pohlenz, V. (2011) Aquisição do conhecimento - fronteiras cognitivas: a linguagem no processo de aprendizagem com fundamento na neurociência. [Knowledge acquisition - cognitive frontiers: language in the learning process based on neuroscience.] Ágora Revista de Divulgação Científica 18(2): 104-19.

Santos, L. G., Madeira, K. \& Longen, W. C. (2017) Prevalência de dor autorreferida na coluna vertebral no Brasil: resultados da pesquisa nacional da saúde. [Prevalence of self-reported pain in the spine in Brazil: results of the national health survey.] Coluna/Columna. 16(3): 198-201.

Santos, A. B. dos, Cardoso, S. L. M., Siqueira, M. da C. C. (2021) The nurse in indigenous health: a literature review. Research, Society and Development, [S. l.], 10(16), e259101624004. 10.33448/rsd-v10i16.24004. Disponível em: https://rsdjournal.org/index.php/rsd/article/view/24004.

Zachrisson-Forssell, M. (1981) The Swedish Back School. Physiotherapy 4:112-4.

Zaro, M. A., Rosat, R. M., Meireles, L. O. R., Spindola, M., Azevedo, A. M. P, Bonini-Rochaf, A. C. \& Timmg, M. I (2010) Neuroeducation emergence: the time and place for neuroscience to add value to educational research. Ciências \& Cognição 15(1): 199-210. 